\author{
DEPARTMENT OF ECONOMICS \\ COLLEGE OF BUSINESS AND ECONOMICS \\ UNIVERSITY OF CANTERBURY \\ CHRISTCHURCH, NEW ZEALAND
}

Understanding Credit Risk: A Classroom Experiment

by

MAROŠ SERVÁTKA

and

GEORGE THEOCHARIDES

WORKING PAPER

No. $06 / 2007$

Department of Economics

College of Business and Economics

University of Canterbury

Private Bag 4800, Christchurch

New Zealand 
WORKING PAPER No. 06/2007

\title{
Understanding Credit Risk: A Classroom Experiment
}

\author{
by MAROŠ SERVÁTKA ${ }^{1 \dagger}$ and GEORGE THEOCHARIDES ${ }^{2}$
}

11 December, 2007

\begin{abstract}
This classroom experiment introduces students to the notion of credit risk by allowing them to trade on comparable corporate bond issues from two types of markets - investment-grade and high-yield. Investment-grade issues have a lower probability of default than high-yield issues, and thus provide a lower yield. There are three ways in which participants can earn money - from coupon payments, the face value of the bond, and by capital gains. Students learn about the notion of risk and return, how credit risk affects bond prices, as well as some general characteristics of the bond markets.
\end{abstract}

Key Words: Teaching Experiment, Credit Risk, Bond Market, Risk and Return

JEL Classification: A20, C90, D84

Acknowledgements: We thank seminar participants at the 2nd Asia-Pacific Regional Economic Science Association Meeting in Osaka, Japan for helpful suggestions, as well as students from the MBA class of 2009 at SKK GSB for participating in the experiment. We are grateful to the University of Canterbury, College of Business and Economics for financial support. Any errors are our responsibility.

${ }^{1}$ Department of Economics, University of Canterbury, Private Bag 4800, Christchurch 8140, New Zealand, +64-3-364-2825, maros.servatka@canterbury.ac.nz.

2 SKK GSB, Sungkyunkwan University, 53 Myungryun-dong 3-ga, Jongro-gu, Seoul Korea, 110-745, +82-2-740-1516, georghio@skku.edu.

${ }^{\dagger}$ Author for correspondence. 


\section{Introduction}

One of the fundamental factors that determines bond yields is credit risk. This refers to the possibility of default by one of the counterparties in a financial transaction. Default can be triggered by a missed or delayed interest payment, bankruptcy, or a distressed exchange. The probability of default affects the future cash flows, and in turn the current market price of the security. Understanding the concept of credit risk is extremely important and helps to evaluate the compensation that an investor would require for taking extra risk. This is a fundamental, yet challenging topic to Finance students, and the purpose of this classroom experiment is to facilitate this learning process.

Within the bond market, there is a wide variety of instruments carrying various levels of credit risk. For example, investors can choose between Treasury or corporate bonds. Treasury bonds are considered risk-free because they are backed by the full faith and credit of the U.S. government. Consequently, they provide a lower yield than corporate bonds. On the other hand, corporate bonds carry credit risk causing investors to demand a higher return on otherwise similar Treasury issues. Furthermore, the corporate debt market can be further subdivided into the investment-grade market and high-yield (or junk) market. ${ }^{2}$ The investment-grade market consists of issues by companies that usually carry a low level of credit risk, whereas the high-yield market consists of issues by firms that are more risky. Thus, within the corporate bond market, investment-grade issues trade at a higher price/lower yield from comparable high-yield issues. ${ }^{3}$ Information on the credit status of borrowers is usually obtained from rating agencies such as Moody's, Standard \& Poor's, and Fitch. ${ }^{4}$

This article describes a classroom experiment with the purpose of introducing students

\footnotetext{
${ }^{2}$ Within each subgroup, there are further divisions. For example, within the investment-grade sector, there are AAA, AA, A, and BBB-rated issues. The high-yield sector consists of BB, B, CCC, CC, and C-rated issues.

${ }^{3}$ Although in practice corporate yields carry also a nondefault component (maybe due to differential taxation or liquidity issues), for the purpose of this experiment we assume that differences in prices/yields are only due to credit risk.

${ }^{4}$ See Fabozzi (2007) and Sundaresan (2002) for excellent expositions regarding fixed income markets.
} 
to the notion of credit risk. The students are allowed to trade on comparable issues from two types of markets - investment-grade and high-yield markets. Investment-grade issues have a low probability of default, whereas high-yield issues have a high probability of default. Consequently, there is $1 / 20$ and $1 / 5$ probability that an issue will default at the end of a period, for the investment-grade and high-yield sector, respectively. To compensate for the higher risk, junk issues provide a higher yield (coupon). Every trader is endowed with an equal number of securities from both sectors, as well as an amount of cash that is used for trading purposes ${ }^{5}$

This experiment can be applied to a number of MBA or upper-level undergraduate courses - Investments, Fixed Income Securities, or Portfolio Management. It helps students not only in understanding credit risk, but also in general how risk is priced, and the notion of risk and return. Furthermore, it helps instructors to facilitate discussion on other important topics such as the time value of money, the mechanics and general characteristics of the corporate bond market, as well as various market trading strategies.

The remainder of this article proceeds as follows. Section 2 presents some selected papers related to this classroom exercise. They are intended to provide further references and follow up reading. Section 3 describes the experimental design and procedures. Section 4 provides results and experience from the experiment thus far, as well as gives guidelines for the classroom discussion. Section 5 concludes. The appendix provides the detailed instructions given to the students and provides a sample record sheet as well.

\section{Related Literature}

There is a vast experimental literature that tackles various issues in financial markets, at both the research and teaching level. In their seminal papers, Forsythe, Parley, and Plott (1982) examine the progression of asset prices through time using laboratory experiments, while Smith, Suchanek, and Williams (1988) first document the existence of price bubbles.

\footnotetext{
${ }^{5}$ The design is similar to that of Ball and Holt (1998) where the assets have the same fundamental value throughout the experiment, i.e. flat value. However, unlike Ball and Holt (1998), in this experiment we have two assets with different levels of risk and reward.
} 
Plott and Sunder (1988) use laboratory markets to examine how information is aggregated when traders have diverse information. Ball and Holt (1998) design a classroom game that compares the traded prices for an asset to its fundamental value. When traded prices rise above this value, then bubbles and subsequent crashes can develop. Dufwenberg, Lindqvist, and Moore (2005) revisit the concept of bubbles in laboratory financial markets that contain a mixture of experienced and inexperienced traders to examine whether the presence of the latter eliminates bubbles. Oechssler, Schmidt, and Schnedler (2007) investigate using an experiment whether bubbles can actually occur without the existence of dividends.

\section{Experimental Design \& Procedures}

The setup for this experiment closely follows that of Ball and Holt (1998). The exercise takes about 50 to 75 minutes, depending on class size. You should allow 10-15 minutes for discussion. If you run short of time, you can shorten the exercise by decreasing the number of trading periods and/or leave the discussion until the following lecture. However, it is essential to announce the true number of periods before the start of the experiment as this might affect the strategies employed by students.

Some preparation must be done before the class begins. Each student should receive a copy of the instructions provided in the appendix. You will also need to prepare record sheets for each trader to complete during the experiment. We include a sample record sheet in the appendix as well. It might be useful to have transparencies ready, to record the decisions made in each period by each trader, or you might choose to record the decisions on the board. You will also need a 5-sided and a 20-sided die. You can use blue and red colored sheets of paper to represent the two assets. You will need 3 blue and 3 red sheets of paper for each team's endowment of assets. Each trader also starts with 400 points cash account to finance trading. Although you can opt not to give out any money payments (announce that all profits are hypothetical), we encourage you to provide some monetary rewards. You can use an exchange rate to convert the experimental points into real currency to keep the 
rewards at a reasonable level. This make the experiment more interesting to students and makes their decisions salient. Table 1 provides a summary of the experiment.

\section{Table 1 should be inserted around here}

If your class is large and it would be impossible to have each student as a separate trader, you can divide the class into at least five groups of two or three students each. It proves better to have an odd number of students per team, with majority vote deciding the outcome if decisions cannot be made unanimously. Using multiple people per team can also provide opportunities for students to get help from team members, share ideas, and discuss strategies.

Each student will represent a "trader" in this experiment. Codes on the instruction sheets can be pre-marked to identify the traders and save time. Pass out the instructions to students, read them aloud, and at the conclusion of instructions go through the columns of the record sheet with the students to ensure understanding. Clearly explain the auction rules. Answer the students' questions and clarify the objective of the exercise. However, make sure not to suggest any trading strategies as this could compromise the results and learning objectives. In case of groups with multiple members, separate the markets physically to avoid confusion about who belongs to which team and to prevent teams from communicating and colluding with one another. You will also need some students to help with keeping time and recording prices on paper to minimize the possibility of recording error and preserving the data. This is particularly important when you choose to record bids and asks on the board and erase them after every transaction and every period.

There are three ways in which the trading teams can earn money from: 1) A 5 and 20 point dividend (coupon) is received for each existing blue and red asset at the end of each trading period, respectively, 2) they can make profits by buying and selling assets, and 3) the traders receive 100 points cash for any assets (both blue and red) that survive until the last trading period (face value of the bond). The experiment consists of 9 trading periods, 
with the first one used for practice. This helps the students to get acquainted with the terminology and the rules of the experiment. In shorter classes, we recommend setting up the experiment for 5-6 periods. Each period lasts 3 minutes. The timekeeper should inform the class of the time about 30 seconds before the end of the period. Approach all trading teams that own red or blue assets at the end of each trading period, after the dividends for that period have been paid, and throw a 5-sided die once for each red asset and 20-sided die once for each blue asset to determine the ones that default. A throw of "1" results in the destruction of that asset (blue or red), while throws of any other number will allow the owner to keep or trade that asset in the next period. If a "1" comes up, tear up the paper representing the asset. As already mentioned, any asset that is not destroyed by the end of the last period will be redeemed for 100 points. Have each trader calculate and record their profits and cash balance on the record sheet each period while you determine the failures of each asset. The instructions in the appendix explain in detail how to fill out the trader's record sheet.

The experimental setup employs oral double auction as the trading institution. More detailed description of the auction rules along with examples can be found in the instructions. There are two simultaneous asset markets - one for blue and one for red assets. Record the two markets on the transparency (or on the board), clearly indicating which market is blue and which one is red. You will then record the bids and asks that each team submits and announce the transactions. Once the trading period begins, the designated person from each team is free at any time to raise a hand, and when called on, to take one of the following actions: submit a bid expressing a commitment to buy a blue or red asset at a certain price; submit an ask expressing a commitment to sell a blue or red asset at a certain price; accept the bid submitted by another trader, and thus making a transaction to sell; or accept an ask submitted by another trader, and thus making a transaction to buy. In addition, each action by a trader has to identify the asset it is related to. The auction is moderated by the instructor who records the bids on the transparencies and announces the transactions. The 
auction follows the bid/ask improvement rule, i.e. each successive bid has to be higher than the previous one and each successive ask has to be lower that the previous one. Short sales are not permitted, i.e., traders cannot sell the asset that is not in their possession. Traders are allowed to make a purchase only if they have enough cash in hand.

A possible modification or variation to the existing setup is to introduce a third asset that has zero probability of default and consequently has a lower coupon rate. This asset will symbolize a Treasury security and will give the students a better perspective of the type of assets that can be found in the bond market. Another variation is to allow students to short sell. One of the growing markets these days in the U.S. and abroad is the repo market, where corporate or Treasury securities are received as collateral for lending money. The borrowers of money have to also pay a collateral rate. Then short-sellers are using these securities to close out their short positions. Again, this modification might make the experiment more in line with the current setup of the bond markets, and introduce the students to the notion of short selling. Other modifications could involve the use of bonds with the same credit risk but different maturities, or bonds with option-like features, such as callable, or putable bonds. However, we believe that these variations, although interesting and appealing, might compromise the simplicity of experiment and the ease of understanding of the notion of credit risk. Therefore, we recommend running them only as a follow up to the current classroom exercise.

\section{Results \& Classroom Discussion}

The experiment was conducted with a group of 8 students from our MBA class of 2009 . Each student represented a separate trader. The experiment lasted 75 minutes including initial instructional period. After the initial practice period, 8 more periods were carried out. At the end of the experiment, each student was paid an amount of money that was computed based on their performance, i.e., cash in hand at the end of the eight periods. Students earned an average 21.90 USD. The points were exchanged into USD using an 
exchange rate of 50 points $=1$ USD. Figure 1 presents the average transaction price per period, figure 2 shows the number of transactions, while figure 3 shows the range of the bid-ask spread per period for each of the two type of assets.

\section{Figures 1, 2, and 3 should be inserted around here}

Figure 1 shows that as we approach the end of the experiment (maturity of the issues), the transaction prices gradually move towards their fundamental values. From figure 2, one can see that traders start trading cautiously, then the number of transactions pick up as they become more comfortable with their trading strategies, and then again it slows down as we enter the final period. Figure 3 shows a wide range of bid-ask spreads, although it gradually narrows down for the blue asset as we approach the last period.

The classroom discussion can start by drawing on a transparency the above three figures. For the sake of time, you could have transparencies with the axes drawn in advance and plot these figures as you progress through the experiment. You can then ask the students what they think about the expected value of the two assets. To help students, you can first focus the discussion at the value of the two assets at the end of the last period, and then work backwards. There should be a clear understanding and agreement that if the two assets

survive by the end of the last period, then their value is 100 . Working backwards, after the last payment has been made but before the final draw, you should explain that the value of either asset should be again 100; $5+0.95(100)$ for the blue asset, and $20+0.8(100)$ for the red asset. This approach should be continued until it becomes clear to the students that both assets have the same flat, fundamental value throughout the experiment. This implies that a risk-neutral investor should not pay more than 100 for both assets. However, investors have different levels of tolerance to risk. Thus the risk loving investors might want to exploit the risk and rewards provided by the red assets, whereas the risk averse investors might prefer the relative safety provided by the blue assets. At this point the instructor should also ask the students regarding the trading strategies they used. A new discussion 
could then begin of how to invest in credit markets, and what is the main type of risk that traders should be aware of. It should be made clear to the students that in the current setup risk is fairly priced, and then according to the level of risk aversion, they can decide on a suitable strategy.

\section{Conclusion}

Understanding the concept of credit risk, or more generally the connection between risk and return, is a challenging topic for finance students. This simple experiment aims to facilitate this process as well as to help students understand the general mechanics and classifications of the bond market. It can also stimulate the discussion on bubbles, speculation, and the effects of risk aversion on investment strategies. More sophisticated setups could involve the ability to short-sell, the introduction of a third asset with zero credit

risk symbolizing the Treasury market, the introduction of bonds with different maturities, or bonds with option-like features, i.e. callable, putable bonds. However, we believe that the simplicity of this basic setup is important for helping students understand these basic, but challenging concepts of financial markets. This design can be applied to a number of MBA or undergraduate classes, such as Fixed-Income Markets, Investments, or Portfolio Management.

\section{REFERENCES}

Ball, Sheryl B., and Charles A. Holt, 1998, Classroom games: Bubbles in an asset market, Journal of Economic Perspectives 12(1): 207-218.

Dufwenberg, Martin, Tobias Lindqvist, and Evan Moore, 2005, Bubbles and experience: An experiment, American Economic Review 95(5):1731-1737.

Fabozzi, Frank J., 2007, Bond markets, analysis, and strategies, 6th edition, Pearson Prentice Hall. 
Forsythe, Robert, Thomas R. Palfrey, and Charles R. Plott, 1982, Asset valuation in an experimental market, Econometrica 50:537-567.

Oechssler, Jörg, Carsten Schmidt, and Wendelin Schnedler, 2007, Asset bubbles without dividends - An experiment, Working Paper.

Plott, Charles R., and Shyam Sunder, 1988, Rational expectations and the aggregation of diverse information in laboratory security markets, Econometrica 56:1085-1118.

Smith, Vernon L., Gerry L. Suchanek, and Arlington W. Williams, 1988, Bubbles, crashes and endogenous expectations in experimental spot asset markets, Econometrica 56:11191151.

Sundaresan, Suresh M., 2002, Fixed income markets and their derivatives, 2nd edition, South-Western, Thomson Learning. 


\section{APPENDIX: Instructions}

This experiment will set up a financial market. Traders will be given both cash and paper bonds that pay future coupons. Traders need to make decisions as to what their paper assets are worth so that they can decide at what prices they would be willing to buy or sell assets. The detailed structure of the game is as follows:

\section{Players and Assets}

TRADING PLAYERS: There are 8 trading players: A, B, C, D, E, F, G and H. In addition, some of you will help with keeping time, recording prices, etc.

ASSETS: Each player starts with:

1. Six different assets, three of which are represented by sheets of blue colored paper and the other three by red colored paper.

2. 400 point cash account that can be used for buying other assets.

EARNINGS: Trading players make money from:

1. collecting a 5 point dividend paid on each blue asset at the end of each trading period.

2. collecting a 20 point dividend paid on each red asset at the end of each trading period.

3. buying and selling assets.

4. cashing in 100 points for any assets (both blue and red) that survive until end of the eighth trading period.

FAILURES: There is a $20 \%$ chance that the red asset will fail after each dividend payment and $5 \%$ chance that the blue asset will fail. Once an asset fails, it is worthless, and I will tear up the sheet of paper that represents the asset. To determine failures, I will come to all trading teams that own red or blue assets at the end of each trading period, after the dividends for that period have been paid, and do a ruffle where a pick of " 1 " will result in the destruction of the blue asset while a pick of either "1", "2", "3", or " 4 " will result in the destruction of the red asset. Throws of any other number will allow the owner to keep or trade that asset in the next period. As already noted, any asset that survives by the end of period 8 will be redeemed for 100 points.

\section{Trading Rules}

TWO MARKETS: There will be two markets - one for blue and one for red assets.

TRADERS: Once the trading period begins, each trader is free at any time to raise a hand, and when called on, to make one of several statements: a BID that expresses a commitment to buy an asset at a certain price; an ASK that expresses a commitment to sell an asset at a certain price; accepting the BID price given by another trader, and thus making a transaction to sell; or the acceptance of an ASK price given by another trader, and thus making a transaction to buy.

BIDS: If trader A wishes to BUY a RED asset at 158 cents, the trader A should place a BID for RED asset at 158 cents. The bid tells others that trader A is willing to buy one red asset from any of them at a price of 158 cents. 
ASKS: If trader B wishes to SELL a BLUE asset at 189 cents, trader B should place an ASK for BLUE asset at 189 cents. The ask tells all other traders that trader B is willing to sell one blue asset to any of them at a price of 189 cents.

TRADERS: Suppose that the highest bid for a red asset is 158, from trader A, and the lowest ask for a red asset is 181, from trader B. Any of the traders who own assets can then decide whether or not they want to sell a red asset to trader A in exchange for 158 cents. If some trader wishes to sell, they must raise their hand, and when called on, say, "I hit A's bid for red asset of 158." Similarly, any of the other traders with sufficient cash on hand can decide whether or not to buy from trader B in exchange for 181 cents. If some trader wishes to buy, they must raise their hand, and when called on, say "I take B's offering of red asset at 181." Instead of accepting someone else's bid or ask, a trader may simply enter a new bid or ask.

BID/ASK IMPROVEMENT RULE: I will record bids and asks for red and blue assets in the two respective tables as follows:

\begin{tabular}{l|l}
\multicolumn{2}{c}{ RED } \\
BIDS & ASKS \\
\hline A 158 & B 181 \\
C 159 & D 179 \\
A 162 &
\end{tabular}

A new bid must be higher than the highest outstanding (untaken) bid, and a new ask must be lower than the lowest outstanding (untaken) ask. For example, the next bid must be above A's bid of 162, and the next ask must be below 179 .

TRADES: A trade occurs only when one trader accepts another's bid or ask. When this occurs, someone from the seller's team should immediately deliver the sheet of paper representing the corresponding asset to the buyer's team, and both teams should adjust their cash positions: the buyer's cash goes down by the amount of the price, and the seller's cash goes up by the amount of the price. Once a trade is made, I will circle the price and erase all outstanding bids and asks, which are automatically cancelled. You are free to reenter previous bids or asks, however.

RULES: Any trader may make both bids during a period, but to make a bid you must have enough cash on hand, and to make an ask on blue or red market you must have at least one respective asset, i.e. one sheet of colored paper, blue or red (no short sales). All bids and asks are for a single asset, although you may buy or sell more than one asset during a period.

CLOSING BELL: The period will end after 3 minutes, regardless of whether the traders have completed all the trades they wish to make.

\section{SUMMARY:}

BID to buy and ASK to sell.

You may sell the specified red or blue asset by:

1. announcing an ask that someone else accepts, or

2. accepting someone else's bid price.

You may buy the specified red or blue asset by:

1. announcing a bid that someone else accepts, or 
2. accepting someone else's asking price.

You cannot sell the asset that you do not have.

You cannot purchase an asset with money that you do not have.

\section{RECORD KEEPING}

1. There is a recording table for each period for both assets. Please see the samples for periods 1 and 2 on the next page. Always make sure that you are using the recording table for the correct period and for the correct asset.

2. Your trader letter is listed on the top left corner. The sample is for trader E.

3. Refer to the sample table for period 1 for the red asset. On line (0) notice that you have "Red Assets on Hand" of 3 and a "Cash Balance" of 400. Everyone begins period 1 with the same number of assets ( 3 red, 3 blue) and the same cash balance.

4. Line (1) shows that trader E's first move in period 1 was to sell 1 red asset for 125. Trader E immediately records this amount in the Sale Price column of line 1 . The Red Assets on Hand decrease from 3 to 2, and the cash balance increases from 400 to 525 .

5. Line (2) shows that trader E's second move was to buy 1 red asset for 150 . This price is immediately recorded in the Purchase Price column of line 2. The Red Assets on Hand increase from 2 to 3 , and the cash balance decreases by the amount of the purchase price, from 525 down to 375 .

6. Line (3) shows that the trader's third move in the period was to buy a red asset.

7. Line (4) shows that the trader's fourth move in the period was to sell a blue asset.

8. Once the period is over, the trader records his/her final cash balance (the bottom number in the Cash Balance column) on line A near the bottom of the table. The number of blue assets is multiplied by the dividend amount of 5 cents per blue asset to obtain the total dividends from blue assets for the period. In this case, $2 * 5=10$, which is entered in the right column of line B. The number of red assets is also multiplied by the dividend amount of 20 cents per red asset to obtain the total dividends from red assets for the period. In this case, $4 * 20=80$, which is entered in the right column of line $\mathrm{C}$. The end-period Cash Balance is obtained by adding the sums in lines A, B, and $\mathrm{C}$ and entering the sum $(325+10+80=415)$ in the right column of line D.

9. After the dividends are paid, we will come to each team holding red and blue assets, and we will do the ruffle. If the outcome for the blue asset is " 1 ", the asset will be torn up. If the outcome for the red asset is " 1 ", " 2 ", " 3 ", or " 4 ", the asset will be torn up. Then the number of remaining assets is entered in the Assets-on-Hand column of the table for the next trading period. The end-of-period cash balance is also transferred to the top of the Cash Balance column for the next period.

10. There will be 8 trading periods and any asset that has not been torn up by the end of period 8 will be redeemed for 100 .

11. Please keep track of your team's earnings carefully, and raise your hand if you have any questions during the trading process.

Are there any questions?

Now please find your recording table for period 1. The red and blue markets are now open for bids and asks. Please do not call out a price until you are recognized. 


\section{Sample Recording Sheet}

Trader E

Trading Period 1

\begin{tabular}{|c|c|c|c|c|c|c|}
\hline & $\begin{array}{l}\text { Type of Asset } \\
\text { (Blue or Red) }\end{array}$ & $\begin{array}{l}\text { Sale } \\
\text { Price }\end{array}$ & $\begin{array}{l}\text { Purchase } \\
\text { Price }\end{array}$ & $\begin{array}{c}\text { Blue Assets } \\
\text { on Hand }\end{array}$ & $\begin{array}{c}\text { Red Assets on } \\
\text { Hand }\end{array}$ & $\begin{array}{c}\text { Cash } \\
\text { Balance }\end{array}$ \\
\hline 0 & & & & 3 & 3 & 400 \\
\hline 1 & red & 125 & & 3 & 2 & 525 \\
\hline 2 & red & & 150 & 3 & 3 & 375 \\
\hline 3 & red & & 150 & 3 & 4 & 225 \\
\hline 4 & blue & 100 & & 2 & 4 & 325 \\
\hline 5 & & & & & & \\
\hline $\mathrm{A}$ & & & & & last cash balance & 325 \\
\hline $\mathrm{B}$ & & & & & $\#$ blue assets $* 5$ & 10 \\
\hline $\mathrm{C}$ & & & & & $\#$ red assets $* 20$ & 80 \\
\hline $\mathrm{D}$ & & & & & end-of-period cash & 415 \\
\hline
\end{tabular}

Trader E

Trading Period 2

\begin{tabular}{|cccccc|}
\hline $\begin{array}{c}\text { Type of Asset } \\
\text { (Blue or Red) }\end{array}$ & $\begin{array}{c}\text { Sale } \\
\text { Price }\end{array}$ & $\begin{array}{c}\text { Purchase } \\
\text { Price }\end{array}$ & $\begin{array}{c}\text { Blue Assets } \\
\text { on Hand }\end{array}$ & $\begin{array}{c}\text { Red Assets on } \\
\text { Hand }\end{array}$ & $\begin{array}{c}\text { Cash } \\
\text { Balance }\end{array}$ \\
\hline 0 & & & 2 & 4 & 415 \\
\hline
\end{tabular}


Recording Sheets for Periods 1-8

Trader

Trading Period 1

\begin{tabular}{|c|c|c|c|c|c|c|}
\hline & $\begin{array}{c}\text { Type of Asset } \\
\text { (Blue or Red) }\end{array}$ & $\begin{array}{c}\text { Sale } \\
\text { Price }\end{array}$ & $\begin{array}{c}\text { Purchase } \\
\text { Price }\end{array}$ & $\begin{array}{c}\text { Blue Assets } \\
\text { on Hand }\end{array}$ & $\begin{array}{c}\text { Red Assets on } \\
\text { Hand }\end{array}$ & $\begin{array}{c}\text { Cash } \\
\text { Balance }\end{array}$ \\
\hline 0 & & & & 3 & 3 & 400 \\
\hline 1 & & & & & & \\
\hline 2 & & & & & & \\
\hline 3 & & & & & & \\
\hline 4 & & & & & & \\
\hline 5 & & & & & last cash balance & \\
\hline A & & & & & \# blue assets * 5 & \\
\hline B & & & & & \# red assets *20 & \\
\hline C & & & & & end-of-period cash & \\
\hline D & & & & & \\
\hline
\end{tabular}

Trader

Trading Period 2

\begin{tabular}{|c|c|c|c|c|c|c|}
\hline & $\begin{array}{c}\text { Type of Asset } \\
\text { (Blue or Red) }\end{array}$ & $\begin{array}{c}\text { Sale } \\
\text { Price }\end{array}$ & $\begin{array}{c}\text { Purchase } \\
\text { Price }\end{array}$ & $\begin{array}{c}\text { Blue Assets } \\
\text { on Hand }\end{array}$ & $\begin{array}{c}\text { Red Assets on } \\
\text { Hand }\end{array}$ & $\begin{array}{c}\text { Cash } \\
\text { Balance }\end{array}$ \\
\hline 0 & & & & & & \\
\hline 1 & & & & & & \\
\hline 2 & & & & & & \\
\hline 3 & & & & & & \\
\hline 4 & & & & & & \\
\hline 5 & & & & & last cash balance & \\
\hline A & & & & & \# blue assets * 5 & \\
\hline B & & & & & \# red assets * 20 & \\
\hline C & & & & & end-of-period cash & \\
\hline D & & & & & \\
\hline
\end{tabular}

Trader

Trading Period 3

\begin{tabular}{|c|c|c|c|c|c|c|}
\hline & $\begin{array}{c}\text { Type of Asset } \\
\text { (Blue or Red) }\end{array}$ & $\begin{array}{c}\text { Sale } \\
\text { Price }\end{array}$ & $\begin{array}{c}\text { Purchase } \\
\text { Price }\end{array}$ & $\begin{array}{c}\text { Blue Assets } \\
\text { on Hand }\end{array}$ & $\begin{array}{c}\text { Red Assets on } \\
\text { Hand }\end{array}$ & $\begin{array}{c}\text { Cash } \\
\text { Balance }\end{array}$ \\
\hline 0 & & & & & & \\
\hline 1 & & & & & & \\
\hline 2 & & & & & & \\
\hline 3 & & & & & & \\
\hline 4 & & & & & & \\
\hline 5 & & & & & last cash balance & \\
\hline A & & & & & \# blue assets * 5 & \\
\hline B & & & & & \# red assets * 20 & \\
\hline C & & & & & end-of-period cash & \\
\hline D & & & & & \\
\hline
\end{tabular}


Trader

Trading Period 4

\begin{tabular}{|c|c|c|c|c|c|c|}
\hline & $\begin{array}{c}\text { Type of Asset } \\
\text { (Blue or Red) }\end{array}$ & $\begin{array}{c}\text { Sale } \\
\text { Price }\end{array}$ & $\begin{array}{c}\text { Purchase } \\
\text { Price }\end{array}$ & $\begin{array}{c}\text { Blue Assets } \\
\text { on Hand }\end{array}$ & $\begin{array}{c}\text { Red Assets on } \\
\text { Hand }\end{array}$ & $\begin{array}{c}\text { Cash } \\
\text { Balance }\end{array}$ \\
\hline 0 & & & & & & \\
\hline 1 & & & & & & \\
\hline 2 & & & & & & \\
\hline 3 & & & & & & \\
\hline 4 & & & & & & \\
\hline 5 & & & & & last cash balance & \\
\hline A & & & & & \# blue assets *5 & \\
\hline B & & & & & \# red assets * 20 & \\
\hline C & & & & & end-of-period cash & \\
\hline D & & & & & \\
\hline
\end{tabular}

Trader

Trading Period 5

\begin{tabular}{|c|c|c|c|c|c|c|}
\hline & $\begin{array}{c}\text { Type of Asset } \\
\text { (Blue or Red) }\end{array}$ & $\begin{array}{c}\text { Sale } \\
\text { Price }\end{array}$ & $\begin{array}{c}\text { Purchase } \\
\text { Price }\end{array}$ & $\begin{array}{c}\text { Blue Assets } \\
\text { on Hand }\end{array}$ & $\begin{array}{c}\text { Red Assets on } \\
\text { Hand }\end{array}$ & $\begin{array}{c}\text { Cash } \\
\text { Balance }\end{array}$ \\
\hline 0 & & & & & & \\
\hline 1 & & & & & & \\
\hline 2 & & & & & & \\
\hline 3 & & & & & & \\
\hline 4 & & & & & & \\
\hline 5 & & & & & last cash balance & \\
\hline A & & & & & \# blue assets * 5 & \\
\hline B & & & & & \# red assets * 20 & \\
\hline C & & & & & end-of-period cash & \\
\hline D & & & & & \\
\hline
\end{tabular}

Trader

Trading Period 6

\begin{tabular}{|c|c|c|c|c|c|c|}
\hline & $\begin{array}{c}\text { Type of Asset } \\
\text { (Blue or Red) }\end{array}$ & $\begin{array}{c}\text { Sale } \\
\text { Price }\end{array}$ & $\begin{array}{c}\text { Purchase } \\
\text { Price }\end{array}$ & $\begin{array}{c}\text { Blue Assets } \\
\text { on Hand }\end{array}$ & $\begin{array}{c}\text { Red Assets on } \\
\text { Hand }\end{array}$ & $\begin{array}{c}\text { Cash } \\
\text { Balance }\end{array}$ \\
\hline 0 & & & & & & \\
\hline 1 & & & & & & \\
\hline 2 & & & & & & \\
\hline 3 & & & & & & \\
\hline 4 & & & & & & \\
\hline 5 & & & & & last cash balance & \\
\hline A & & & & & \# blue assets * 5 & \\
\hline B & & & & & \# red assets * 20 & \\
\hline C & & & & & end-of-period cash & \\
\hline D & & & & & & \\
\hline
\end{tabular}


Trader

Trading Period 7

\begin{tabular}{|c|c|c|c|c|c|c|}
\hline & $\begin{array}{c}\text { Type of Asset } \\
\text { (Blue or Red) }\end{array}$ & $\begin{array}{c}\text { Sale } \\
\text { Price }\end{array}$ & $\begin{array}{c}\text { Purchase } \\
\text { Price }\end{array}$ & $\begin{array}{c}\text { Blue Assets } \\
\text { on Hand }\end{array}$ & $\begin{array}{c}\text { Red Assets on } \\
\text { Hand }\end{array}$ & $\begin{array}{c}\text { Cash } \\
\text { Balance }\end{array}$ \\
\hline 0 & & & & & & \\
\hline 1 & & & & & & \\
\hline 2 & & & & & & \\
\hline 3 & & & & & & \\
\hline 4 & & & & & & \\
\hline 5 & & & & & last cash balance & \\
\hline A & & & & & \# blue assets *5 & \\
\hline B & & & & & \# red assets * 20 & \\
\hline C & & & & & end-of-period cash & \\
\hline D & & & & & \\
\hline
\end{tabular}

Trader

Trading Period 8

\begin{tabular}{|c|c|c|c|c|c|c|}
\hline & $\begin{array}{c}\text { Type of Asset } \\
\text { (Blue or Red) }\end{array}$ & $\begin{array}{c}\text { Sale } \\
\text { Price }\end{array}$ & $\begin{array}{c}\text { Purchase } \\
\text { Price }\end{array}$ & $\begin{array}{c}\text { Blue Assets } \\
\text { on Hand }\end{array}$ & $\begin{array}{c}\text { Red Assets on } \\
\text { Hand }\end{array}$ & $\begin{array}{c}\text { Cash } \\
\text { Balance }\end{array}$ \\
\hline 0 & & & & & & \\
\hline 1 & & & & & & \\
\hline 2 & & & & & & \\
\hline 3 & & & & & & \\
\hline 4 & & & & & & \\
\hline 5 & & & & & last cash balance & \\
\hline A & & & & & \# blue assets * 5 & \\
\hline B & & & & & \# red assets *20 & \\
\hline C & & & & & end-of-period cash & \\
\hline D & & & & & \\
\hline
\end{tabular}


Table 1. Summary of the Experiment

Course Investments, Fixed Income Markets, Portfolio Management

Level

Subject

Class Size

Undergraduate, MBA

Time

Credit Risk, Risk and Return, Bond Market Mechanics

Variation

8 or more students

50-75 minutes

Addition of a third type of security (Treasury), ability to short sell, securities with same credit risk but different maturities, callable and putable issues

Requirements

Blue and red paper; for a class of 8 traders, you need 24

blue and 24 red assets. Also, a 5-sided and a 20-sided die, otherwise an empty jar to perform a ruffle 


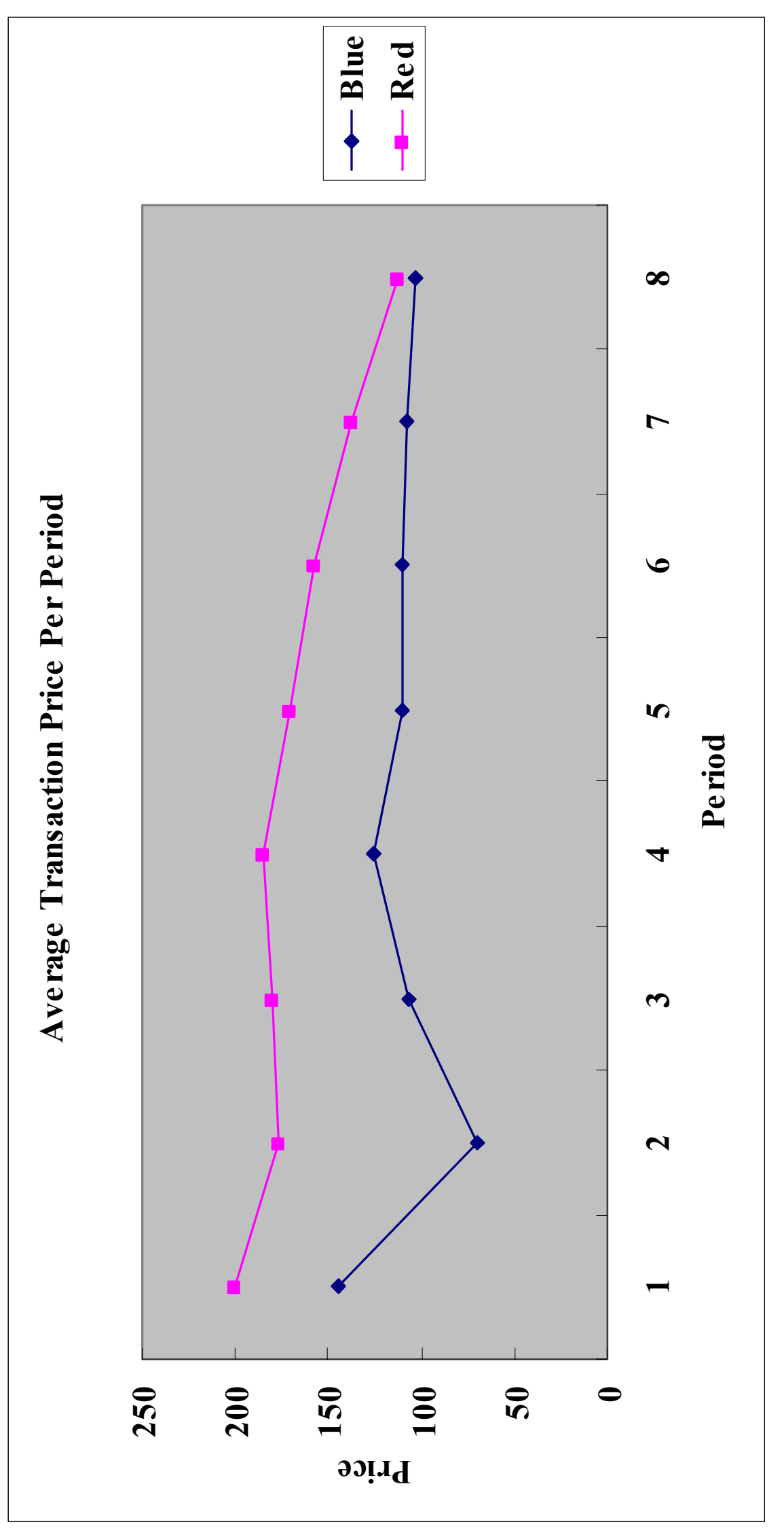

옹

.

ळ

:

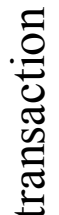

8

넘

일

产

产

量

苛

ळ

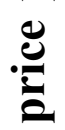

氠

ช్

ซี่

$\Xi \frac{\dot{0}}{0}$

कू బै

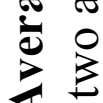

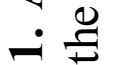

눙

일 

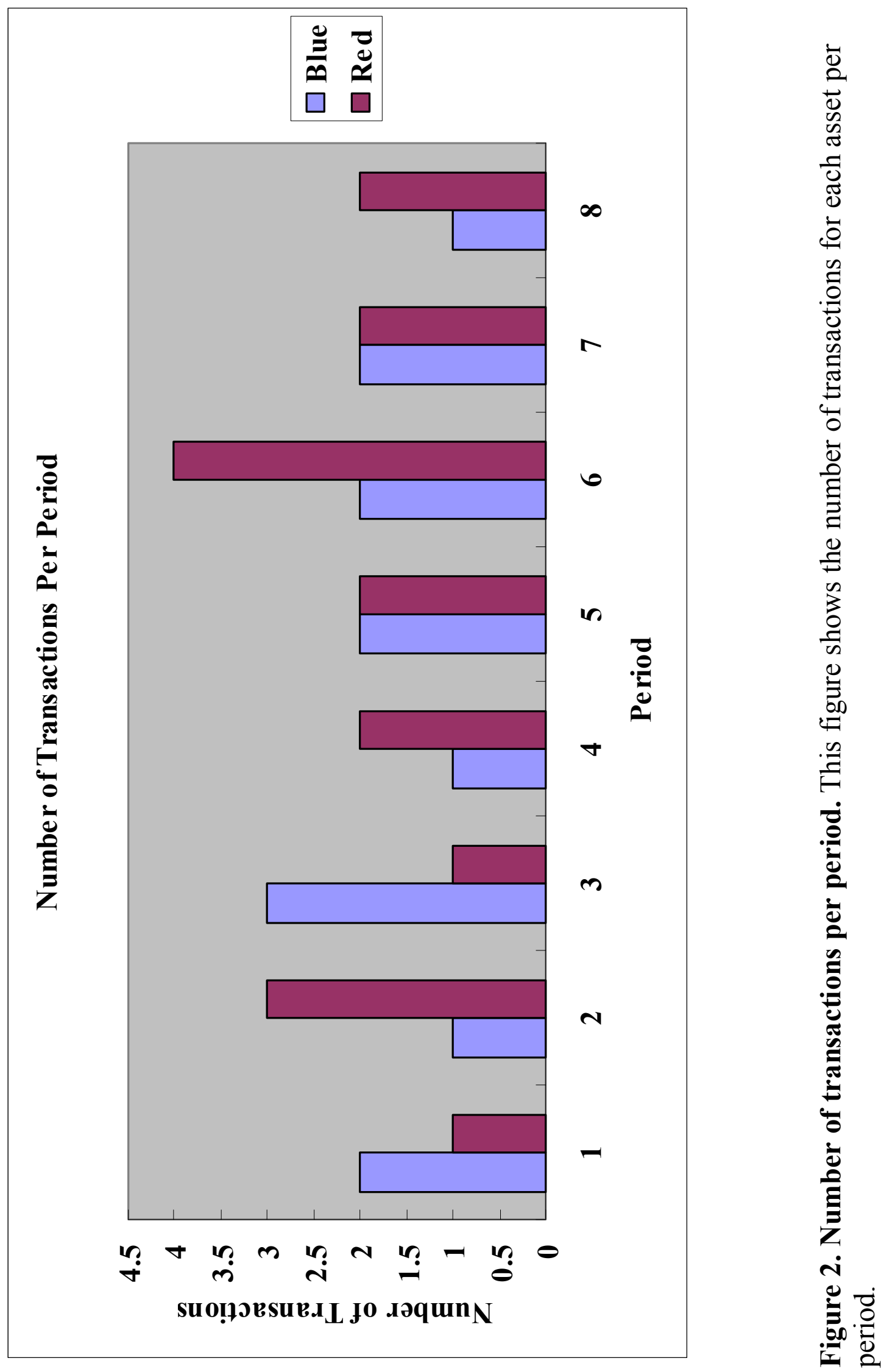


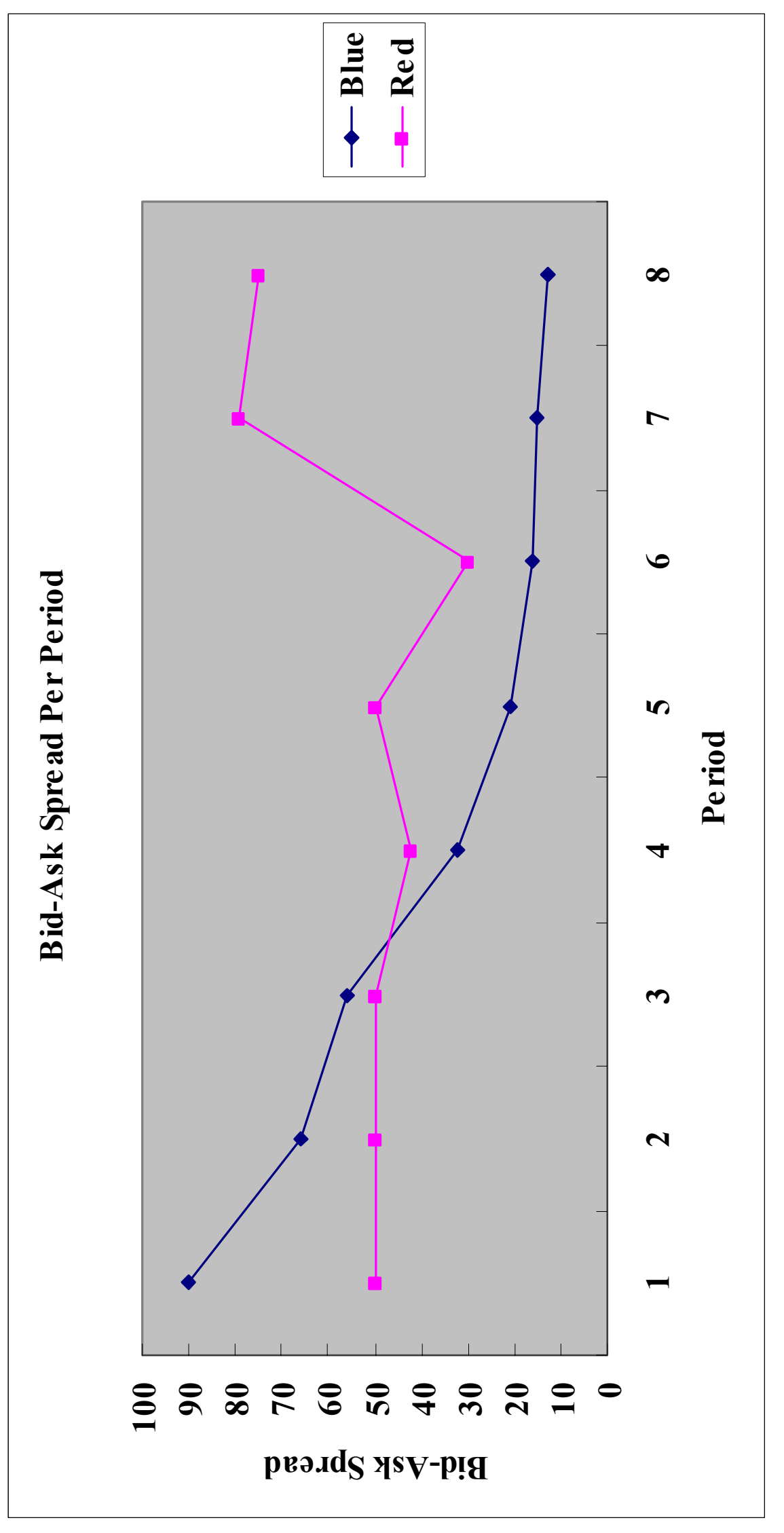

$\overline{0}$

范

$\frac{\pi}{8}$

ช

훙

:

$\frac{4}{5}$

등

궁

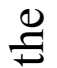

อี

on

స్త్ర

$\stackrel{0}{\Xi}$

as

$\frac{8}{2}$

苛

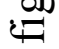

E

을

¿

चี

ن் 